\title{
THE BACHELOR PROGRAMME IN CIRCULAR ECONOMY: EXPERIENCE OF THE REPUBLIC OF POLAND
}

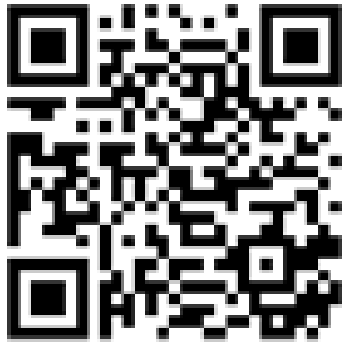

To cite this article:

\author{
Oleksii Sysoiev, PhD in Economics \\ Head, Licensing and Accreditation Department, \\ Kyiv International University \\ Kyiv, Ukraine \\ 4998858@gmail.com \\ https://orcid.org/0000-0001-5899-0244
}

Sysoiev, O. (2021). Bachelor program in circular economy: experience of the republic of Poland. Education: Modern Discourses, (4), 146-152.

https://doi.org/10.37472/2617-3107-2021-4-14

Abstract. The paper is focused on the analysis of the studying program in the circular economy for bachelors at the Silesian Polytechnic of the Republic of Poland. The training first introduced in Poland in 2018, is practice-oriented and aimed at systematic training of bachelors to implement the tasks of the circular economy. The research material is the studying programme for bachelors in the circular economy at the Silesian Polytechnic. The paper presents the analysis of the structure, the studying hours, subjects, activities, and project-based method. The paper shows that bachelor's training is practice-based using modern learning technologies, in particular the implementation of both educational projects and projects in a specific production. It is concluded that the study and analysis of studying programme in the circular economy at the bachelor level in the Republic of Poland allow us to implement Polish experience in designing training courses in higher education to provide green economy ideas in Ukraine.

Keywords: bachelor in the circular economy; education and training; higher education; studying program.

\section{INTRODUCTION}

The global world is increasingly faced with problems caused by technological development, digitalization of social life, and economy at national and international levels, aggravating humanity's survival on Earth. The issues of environmental and energy safety, waste-free production, waste processing, water purification - the issues of human life safety arose. That is why a circular economy is acquiring such great importance globally and in the European Union as well.

Businesses extract natural resources and sell their products to consumers, who throw them away when they no longer use them. Analysing the linear economic model Jonker (2019) reveals that our natural resources are reduced, and waste generated increases. A circular economy suggests what raw materials and products will remain in circulation for as long as possible, and their value will be maximized. As a result, we will extract fewer natural resources, generate less waste and reuse what we have already created.

Scientists identify several principles that govern the circular economy (Gospodarka obiegu zamkniĊtego, 2018). The first step to realizing them is understanding how materials circulate in 
a closed loop. In a circular economy, materials circulate in two separate cycles - biological and technical or synthetic. Since they are processed in different processes, it is essential to separate the materials from each other. Then after using it will be possible to restore them, and they can undergo another treatment. Recovering technical materials such as fossil fuels, plastics, and metals, often found in electronic devices, is essential for conservation. It can be done primarily by repairing existing products and recycling them properly. In addition, recoverable biological materials such as water and food, if not contaminated, are absorbed into the ecosystem after use.

The formulation of moving into a circular economy in Ukraine is outlined in the National Economic Strategy 2030. The Strategy notes that decarbonization of the economy (increasing energy efficiency, developing renewable energy sources, developing a circular economy, and synchronization with the European Green Deal initiative) are essential tasks for the Ukrainian economy (Tsentr ekonomichnoho vidnovlennia, 2021).

For achieving an economic vision, the mission of this Strategy is to create opportunities for the implementation of the existing geographic, resource, and human potential of the country to ensure an appropriate level of well-being, self-realization, security, rights and freedoms of every citizen of Ukraine through innovative advanced economic growth, taking into account the goals sustainable development and the need to achieve climate neutrality no later than 2060 (Tsentr ekonomichnoho vidnovlennia, 2021).

This document testifies to the country's determination to take a course towards the green transformation of the national economy. The new format of the economy will require a 'green' labour force at the circular labour market. Therefore, during the transition from linear to the circular economy, higher education plays an essential role in education and training 'green' professionals in various economic sectors.

Literature review shows that the issue of training professionals in higher education is widely discussed in national and international discourses. Scientists devote the works to $\mathrm{PhD}$ training (Sysoieva et al., 2018), teacher training (Mospan, 2016), teacher training for the circular economy (Bugallo-Rodríguez and Vega-Marcote, 2020). Besides, the recent researches are focused on current trends in higher education and circular economy transition, for example, the role of universities in sustainable development and circular economy (Sukiennik et al., 2012), studying programs at university (Qu et al., 2020), developing competencies in the circular economy (Sumter et al., 2021; Wiek et al., 2011). However, the issue of higher education and training in the circular economy is still a new topic for the national educational area.

It is worth mentioning that an important innovation of the Law "On Higher Education" of Ukraine is obtaining the right of universities to independently develop and implement scientific and educational programs (Sysoeva \& Mospan, 2015, p. 167). Accordingly, in the new transition conditions to a circular economy, HEIs will begin to offer new educational programs for training "green" professionals. However, this issue has not received systematic consideration in our country. Therefore, the study of the experience of the leading countries is of crucial importance. One of the first provided education and training in the circular economy is the Republic of Finland. Next is our closest neighbour - the Republic of Poland which is making significant steps in the circular economy transition and developing studying programs in this field.

The purpose of the paper is to analyse the experience of the Republic of Poland in providing educational services in a circular economy in higher education. The research material is the studying program for bachelors in the circular economy at the Silesian Polytechnic.

Description of the studying programme for bachelors in the circular economy. Since the 2018-2019 academic years, the Silesian Polytechnic in Glivik has opened a new direction for education and training in the circular economy at the bachelor's level. The programme lasts 
3.5 years and fully meets the needs of the sustainable development of society. The purpose of the new direction in education and training in the circular economy is to extend the life of raw materials, materials and products, and turn the resulting waste into secondary raw materials. This approach to the economy is a current trend in the most developed countries and, according to experts, will soon become a mandatory practice for the economies worldwide (Gospodarka obiegu zamkniĊtego, 2018).

The new studying programme "Circular Economy" trains engineers at the bachelor level of higher education. The duration of study is 3.5 years ( 7 semesters). The basic knowledge acquired by students includes knowledge of the natural resources of the Earth; knowledge of waste management; knowledge of the possibilities to create new products based on the GOZ rules; knowledge of chemical and biological processes used to restore energy and valuable substances (Gospodarka obiegu zamkniĊtego, 2018).

In addition, in the learning process, students receive:

- knowledge about the natural resources of the land, the use of raw materials in production processes and the risks associated with their consumption;

- the ability to assess the life cycles of industrial products; knowledge of the basics of managing waste streams generated in different sectors of the economy;

- knowledge in the field of chemical, biological and physical processes for waste processing and the ability to select them for the recovery of energy and valuable substances, observing the principles of environmental protection;

- the knowledge that allows getting energy and valuable substances from renewable resources in order to replace traditionally used raw materials, respecting the principles of environmental protection;

- studying the basics of creating new products based on a circular economy;

- the formation of skills necessary to assess the environmental safety of the newly introduced product;

- the formation of skills that allow creating new technologies and products;

- acquiring the ability to work in a team, performing different roles in it;

- creative development of skills for finding new information and solving interdisciplinary problems (at the border of different disciplines);

- acquisition of basic skills in the field of technical concepts, work results and selfpresentation.

It should be noted that the vocational training programme defines where such specialists can work. After completing the course "Circular Economy," the graduates can work in various economic sectors, particularly in energy, construction, transport, utilities, mining, heavy industry, medical and pharmaceutical, industrial processing and agriculture.

Moreover, graduates can work in design and construction bureaus; manufacturing and trade enterprises; in organizations that care about industrial and hazardous waste; institutions of communal services (institutions that take care of municipal waste, sewage treatment); state administration and local government leadership (ministries, county governor, city and other government bodies); research institutes and higher schools, dealing with the problems of waste use and processing; at biogas plants and other establishments producing electrical energy, heat from energy plants, agricultural and consumer waste, waste streams for animal feeding; research and consulting companies creating technologies and devices for the circular economy; institutions responsible for the development and transfer of technologies; business incubators.

The studying programme emphasizes that graduates receive interdisciplinary knowledge not only in the circular economy but also in the planning, design and operation of technological processes, devices and installations for the management and disposal of municipal, industrial, hazardous waste, and environmental monitoring (Gospodarka obiegu zamkniĊtego, 2018). 
Furthermore, the studying program provides flexible forms of studying - individually or in groups. Future professionals receive training for:

- creative solution of problems related to planning, design and operation in the field of circular economy (circular economy);

- management and collaboration with specialists from other industries at every stage of the design process, from programming to investment or during the operation phase;

- solving design and construction problems using modern computer technologies;

- analysis in research laboratories.

The skills that specialists of the Circular Economy direction should master include such modern essential skills as working in groups, searching and analysing data and conclusions, self-presentation and public speaking, critical thinking, the argumentation of their judgments and discussions.

It is important to note that graduates have the opportunity to choose a scientific career after completing their course in the engineering, graduates can continue their studies at the master's level and then at the doctoral level (Gospodarka obiegu zamkniĊtego, 2018).

The course in the circular economy is available for training only for full-time students. In practice, this means that classes are held from Monday to Friday, which is ideal for students devoted entirely to learning and education. Therefore, the studying program "Circular Economy" includes mainly economic and technical sciences.

Concerning the curriculum and individual subjects, we note that students directly from the circular economy can take advantage of a wide range of training courses thematically related to biological, scientific and economic sciences. The class schedule is divided into basic, specialized, and business modules including the following subjects: biochemistry, microbiology, waste management, water renewal, business planning, and business technology.

While studying in the direction mentioned above, students receive essential practical skills to succeed in their future careers. Through numerous workshops, students will learn how to assess the life cycle of industrial products and manage different types of waste. In addition, management and marketing competencies are developed. An integral part of the study is an internship, which provides students with valuable experience of practical professional activity.

Training in the first level at the course "Circular Economy" lasts three and a half years or seven semesters. After that, graduates receive the title of engineer.

Thus, the preparation of bachelors in the direction of Circular Economy, or Circular Economy, is carried out today at the Silesian Polytechnic, a branch located in the city of Gliwice (Politechnika SląVka w Gliwicach) at the Faculty of Environmental Engineering and Energy, in a stationary form of study, the duration of study at the first level of higher education is 3.5 years (Gospodarka obiegu zamkniĊtego, 2018).

The structure and content of the studying programme in "Circular economy". The structure and content of the studying program in "Circular economy" at the Silesian University of Technology are presented in Fig. 1.

The first module (module of non-technical disciplines) includes the following subjects: English language, physical education, humanistic social subjects, subject in economics.

The second module (core/professionally oriented module) includes the following subjects: global raw materials, IT tools in engineering, biochemistry, microbiology, intellectual property protection, labour safety and ergonomics, biofuels and plant energy, legal and administrative aspects in a circular economy about materials, thermodynamics, waste economics, heat and mass exchange (transformation), fluid mechanics, bioremediation of raw materials, combustion and other thermal processes, business planning and procedures, assessment of the environmental impact on the entire life cycle / LCA, waste recycling, renewal of water, gas purification technologies, recovery of water and other raw materials from effluents. 


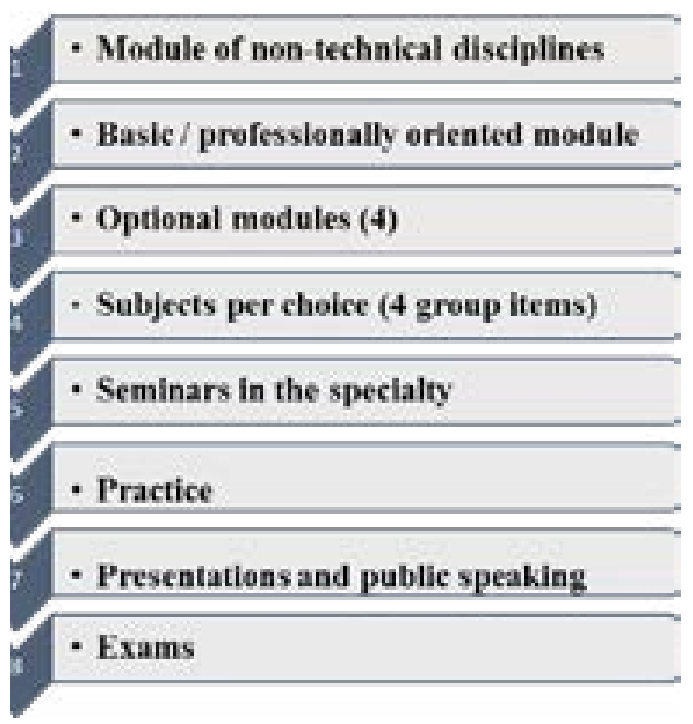

Fig. 1.

Structure of the studying program in "Circular Economy"

Source: Designed by author.

The first elective module contains a subject such as technology entrepreneurship. The second elective module contains a subject such as the best available techniques for the circular economy. The third optional module contains the subject 'unitary processes in the circular economy. Finally, the fourth optional module contains several subjects: examples of good engineering practice.

In addition, the curriculum includes elective subjects. The first subject is energy management in buildings. The second includes the following subjects: local water management, energy storage. Also, this block of the curriculum contains vacation practice (four weeks), presentations and public speeches (45 hours). The third elective subject is called "Current Trends in the Circular Economy".

Moreover, the styling program provides seminars in engineering design. The full course is finished with the exams.

The distribution of hours for individual subjects and study is the following. The first module is focused on studying English (120 hours) provided with practice-based approach. Physical education takes place in the first and second semesters (60 hours) and is a subject for which no credits are accrued. Humanistic and social subjects, as well as subjects in economics are studied only in the first semester (30 hours).

The second main module includes the following subjects as general chemistry (75 hours), mathematics (150 hours), physics ( 90 hours), materials science ( 45 hours) ( $1^{\text {st }}$ semester), and global raw materials ( 45 hours) $\left(2^{\text {nd }}\right.$ semester).

Further, successively (in the second semester), subjects are studied such as IT tools in engineering ( 60 hours), biochemistry ( 60 hours), microbiology (60 hours), intellectual property protection (15 hours), labour safety and ergonomics (15 hours).

In the third semester, subjects such as biofuels and plant energy (60 hours), legal and administrative aspects in the circular economy ( 45 hours), materials science (60 hours), thermodynamics (60 hours), waste economics (90 hours).

As for the fourth semester, the English language study is completed, and the study of the subjects of the main professionally-oriented module continues. In addition, to such items, this semester includes exchange (transformation) of heat and mass (30 hours), fluid mechanics 
(45 hours), bioremediation of raw materials (45 hours), combustion and other thermal processes ( 45 hours), business planning and procedures ( 45 hours), assessment of the impact of the environment on the entire life cycle / LCA (45 hours), waste recycling (45 hours), renewal of water (45 hours), gas purification technologies (45 hours).

The fifth semester exclusively includes optional modules (90 hours) and a subject for a choice (45 hours). In the sixth semester, they further study elective subjects and such academic disciplines as reactor engineering (45 hours), enterprise financial efficiency (60 hours), renewable energy sources (60 hours), distributed energy and consumption systems (60 hours), energy from waste (60 hours).

In the final seventh semester, there is a vacation practice (6 credits), public presentations and speeches ( 45 hours), subjects: energy storage ( 30 hours), current trends in the circular economy (30 hours), a professional seminar (15 hours), an engineering project is being carried out (45 hours).

Regarding the ratio of hours for different forms of training, it can be noted that the total number of hours for the entire training period is 2550 hours. Of these, 975 hours are allocated for lectures, which is $38 \%$ of the study time. 675 hours are allocated for practical training, which is $26 \%$. Seminars are allocated only 15 hours, which is $1 \%$ of the study time. These are, in fact, the hours that come with a professional seminar in the seventh semester. For laboratory work, 465 hours are allocated, which is $18 \%$ of the study time. Also, hours are allocated for implementing research projects, 420 hours, which is $17 \%$ of the study time.

In addition to the time allotted for the implementation of objects in individual subjects, students can carry out a project at an enterprise (industrial project) in the 5th and 6th semesters, for which 180 hours are allotted, at the expense of the hours allocated for academic studies. In the curriculum, hours for an industrial project are prescribed separately from forms of academic study. At the same time, for implementing an industrial project, hours are removed from lecture, practical and laboratory classes, thereby increasing the practical orientation of training and reducing its theoretical component within the university's walls. With such an organization of training, lectures account for only $35 \%$, and the project component is $24 \%$. Therefore, we can conclude that the training of bachelors in the course "Circular Economy" (closed-cycle economy) is practically oriented with a ratio of theoretical and practical training $40 / 60$, or 36/64. Studying hours distribution per semester see in Table 1.

Table 1

\section{Studying hours distribution per semester}

\begin{tabular}{|c|c|c|c|c|c|l|}
\hline \multicolumn{7}{|c|}{ Semester number } \\
\hline $\mathbf{1}$ & $\mathbf{2}$ & $\mathbf{3}$ & $\mathbf{4}$ & $\mathbf{5}$ & $\mathbf{6}$ & $\mathbf{7}$ \\
\hline 25 hours & 26 hours & 25 hours & 28 hours & 27 hours & 28 hours & 11 hours \\
\hline 30 credits & 30 credits & 30 credits & 30 credits & 30 credits & 30 credits & 30 credits \\
\hline No exams & 3 exams & 3 exams & 3 exams & 3 exams & No exams & No exams \\
\hline
\end{tabular}

\section{CONCLUSION}

In conclusion, it can be stated that the Republic of Poland has begun systematic education and training in the circular economy in higher education. However, the training was carried out only in postgraduate education till 2018. Since the 2018/2019 academic year, the education and training of bachelors in the circular economy have begun at Silesian University. 
Analysis of the studying programme in the circular economy at the bachelor level shows that the education and training are practice-based using modern teaching technologies, particularly the implementation of both educational projects and projects in a specific production. At the same time, motivational reasons for implementing production projects are created by reducing hours for academic studies.

It is worth mentioning that, in addition to specialized subjects, considerable attention is paid to English, studied for four semesters. The advantage of the studying program in the circular economy at the bachelor level is the availability of optional subjects and modules that allow students to expand their knowledge, taking into account their own personal and professional interests. In bottom line, the study and analysis of studying program in the circular economy at the bachelor level in the Republic of Poland allow us to implement Polish experience in designing training courses in higher education to provide green economy ideas in Ukraine.

\section{REFERENCES}

Bugallo-Rodríguez, A. \& Vega-Marcote, P. (2020). Circular economy, sustainability and teacher training in a higher education institution. International Journal of Sustainability in Higher Education, 21(7), 1351-1366. https://doi.org/10.1108/IJSHE-02-2020-0049

Gospodarka obiegu zamkniĊtego: szlolenia, studia, warsztaty. (2018). Politechnika ĝOąska. https:// ise.polsl.pl/\%20gospodarka-obiegu-zamknietego.html

Jonker, J. (2019). New Bussines Model. Cirkular Economy. Polish Circular Hotspot. http:// circularhotspot.pl/\%20pl/gospodarka-obiegu-zamknietego

Kulczycka, J. (2019). P. Ćdziwiatr E. Gospodarka o obiegu zamkniĊtym - definicje i ich interpretacje. In J. Kulczycka (Ed.), Gospodarka o obiegu zamkniCtym w polityce i badaniach naukowych (pp. 9-19). Wydawnictwo IGSMiE PAN.

Mospan, N. (2016). Teacher education graduates in Ukraine: Current state of play. Cogent Education, 3, 1-19. http://dx.doi.org/10.1080/2331186X.2016.1221192

Tsentr ekonomichnoho vidnovlennia. (2021). Natsionalna ekonomichna stratehiia 2030. https:// nes2030.org.ua/

Qu, D., Shevchenko, T. \& Yan, X. (2020). University curriculum education activities towards circular economy implementation. International Journal of Scientific and Technology Research, 9(5), 200-206.

Sukiennik M., Zybała K., Fuksa D. \& Kęsek M. (2021). The role of universities in sustainable development and circular economy strategies. Energies, 14(17), 53-65. https://doi. org/10.3390/en 14175365

Sumter, D., de Koning, J., Bakker, C. \& Balkenende, R. (2021). Key Competencies for Design in a Circular Economy: Exploring Gaps in Design Knowledge and Skills for a Circular Economy. Sustainability (Switzerland), 13, 1-15. https://doi.org/10.3390/su13020776

Sysoieva, S. \& Mospan, N. (2015). New Law of Higher Education in Ukraine: innovations and risks. Didactica Slovenica, 30(3-4), 166-174. http://www.pedagoska-obzorja.si/revija/Vsebine/ PDF/DSPO_2015_30_03.pdf

Sysoieva, S., Batechko, N. \& Mospan, N. (2018). Module Piloting for PhD Training: Experience of Ukraine. Journal of Modern Education Review, 8(9), 661-666. http://www.academicstar.us/ issueshow.asp?daid $=2268$

Wiek, A., Withycombe, L. \& Redman, C.L. (2011). Key competencies in sustainability: A reference framework for academic program development. Sustainability Science, 6, 203-218. https:// doi.org/10.1007/s11625-011-0132-6 